\title{
REVEALING THE EFFECTS OF TEACHERS STIMULATING TECHNOLOGICAL INCLUSION ON UNIVERSITY STUDENTS EDUCATIONAL GAINS: A COMPARATIVE STUDY
}

\author{
Mehboob Ul Hassan ${ }^{1^{*}}$, Haq Nawaz ${ }^{2}$, Abu Ul Hassan Faiz ${ }^{3}$ \\ ${ }^{1 *, 2}$ Institute of Education and Research, University of the Punjab, Lahore, Punjab-Pakistan; ${ }^{3}$ Women University Bagh, \\ Azad Jammu and Kashmir-Pakistan. \\ Email: ${ }^{1 *}$ hassanbhattig@ hotmail.com, ${ }^{2}$ haqnawazsheroz@gmail.com, ${ }^{3}$ sabulhussan@gmail.com
}

Article History: Received on $6^{\text {th }}$ June 2021, Revised on $17^{\text {th }}$ June 2021, Published on $18^{\text {th }}$ June 2021

\begin{abstract}
Purpose of the Study: The purpose of the current research was to measure the effect of male and female teachers technological inclusion used to stimulate university students educational gains. The research have intends to determine the effect of current practices occurring in public and private universities of District Lahore of the Province-Punjab.

Methodology: The researchers structured quantitative research leading to a positivist paradigm adopting ex post facto design to determine the effect of public and private universities teachers stimulating technological inclusion on students educational gains. The researchers administered a self-constructed questionnaire on a sample of 600 respondents. The researchers ran regression analysis and independent-sample t-test to find out effect and comparison.
\end{abstract}

Main findings: Findings of regression analysis revealed that teachers stimulating technological inclusion affect $68.70 \%$ of students educational gains whereas critical thinking and problem solving $66.70 \%$, creativity and innovation $66.70 \%$ and, health issues affect $69.10 \%$ of students educational gains. Male teachers were more stimulating their technological inclusion as compared to female teachers. Likewise, private sector university teachers were more stimulating their technological inclusion on their students educational gains as compared to public sector university teachers.

Applications of this study: The results of the current research will be applicable for male and female sector universities teachers working in public and private sectors. They will be realistically aware of the actual use of their technological inclusion used to stimulate their students enrolled in other provinces of the Pakistan including Punjab for acquiring better educational gains. The findings of the research will be pertinent to provoke the intends of future research scholars to establish the effect of technological inclusion on social, political, economical, and cultural transformations aspects, unfolding the technological dimensions of artifact, knowledge, process, and volition.

Novelty/originality of this study: The researchers days-and-nights effort bring fruitful consequences in contributing to this evidence-based literature to the existing body of knowledge in the field of teachers technological inclusion. The authors have tremendously determined the effects of teachers technological inclusion used to stimulate university students didactic learning which was never done before from a Pakistani Perspective. The researchers have covered a similar topic to ensure the relevancy, accuracy, and uniformity to engage the attentions of the readers in data sharing.

Keywords: Creativity and Innovations, Critical Thinking, Educational Gains, Health Issues, Problem-solving, Technological Inclusion.

\section{INTRODUCTION}

Humans thirst to satisfy their needs have been remaining top priorities for decades. Individuals had been living in stone, bronze, industrialization and the modern era vocalized as the digital age. Humans took revolutionary steps to conquer the universe through continuous usage of technological applications that have become a global platform for sharing information, especially in educational institutions. Technology education has pointed guns in every walk of life for eras. Stimulation of technological inclusion is practical and an effective technique that is applied in every field of energy, which reduces humans distances. It fluctuates according to the progressive intensity and necessities of societies (Bennett et al., 2008; Deshpande \& Shesh, 2021; Qaddumi et al., 2021; Supardi et al., 2021). Empirical evidence of contemporary technological progress was observed from 1997-2006. The concept of computer networking with peer-learning was coined, and so-called online digital learning turned into extensive that enabled researchers to explore outfitted emerging technologies (Boulton et al., 2018; Kundu, 2021). Usage of stimulating technological gadgets has attained a valuable place in educational institutions for the students didactic learning (Zawacki-Richter \& Latchem, 2018). Effects of teachers stimulating technological inclusion in the present era are applied for acquiring better educational achievements and remained a top priority for teachers for the teaching-learning process. Innovative approaches of teachers stimulating technological inclusion always put imperative influence on student's educational success. It enhances teachers collaboration with students and parents, incorporating the usage of stimulating technological content for students' understandings (Brok \& Schrøder, 2012). It is holistic thought in intellectual and chronological contexts for technological advancement (Adarkwah, 2021). Teachers technological inclusion enhances students educational outputs informal and non-formal setting (Nikolopoulou et al., 2021), imperatively transforms blue-collar individuals to white collars individuals (Dele-Ajayi et al., 2021), incorporates students cognitive and psychomotor skills (Dong \& Mertala, 2021), make students technological cultured (Tlili et al., 2021) in acquiring better educational gains. 
National Research Council; NRC and National Academy of Engineering; NAE enlightened that technological encompassed three mutual supporting dimensions: individuals potential, understanding, and ways of thinking (Rose et al., 2004). Technology is a crucial driver for human beings to understand the nature of interlinks stimulating technological devices (Li \& Wang, 2021). These devices are personal computers, the internet, electronic messages, and digital gadgets. Human beings must cope with the most recent stimulating technological gadgets. It plays a significant role in enhancing skills and human competencies according to the needs of the 21st Century (Hassan \& Akbar, 2020). Applications of technology consist of technological information, procedures, domino effects and, series of programs which enable individuals to last through the fast through rapid transformation (Fekete, 2021). Technological skilled persons are a constant user of technology, regular information seekers, high-quality communicators and collaborators (Qaddumi et al., 2021), innovators and contributor citizen (International Technology Education Association, 2000), transfers skills to the next generation and knows how to create, work, shape society and how society shapes (Marín et al.., 2021). Intention "to understand", how technology shapes civilization and in turn is "shaped civilization" is the product of stimulating technological inclusion (Kim et al., 2021). It is intolerable to discount the worth of technology in institutions in technological era (Hébert et al., 2021; McGarr \& McDonagh, 2021).

Technology facilitates teachers to understand the appropriate usage of stimulating technological gadgets in institutions (Hébert et al., 2021; McGarr, 2021). Modern devices prepare teachers for the proper use of digital/social media in safe, confidential and wisely (Fuchs, 2021). Teachers realize individuals, communal and cultural issue of technology, then perform authorized and moral actions (Hamilton et al., 2021) and have the potential to prove their knowledge for students understanding. They generate queries then contribute to the discussion. They enhance critical thinking, problem-solving, and decision-making skills through improving rapid use of stimulating technological conversation focusing on ethical aspects among prospective and in-service teachers (Boettcher \& Conrad, 2021). Applications of teachers encouraging technological inclusion produce classrooms challenges towards their work identification and professional identity (Brok \& Schrøder, 2012). However, it is one of the dilemmas that teachers contribute their fewer intentions towards continuous usage of technological applications (Pinho et al., 2021). Teachers use different techniques to make effective teaching which remains helpful and easily fit in classrooms environment (Anderson, 2006). Instinctual; ordinary and predictable situation as a learning tool, hesitant; understand incredible and changeable technological devices, incorporated; addition of innovative stimulating technological aspects for educational use to become addendum and effectual viewpoints; refers to teachers ways of expressions that how technology give freedom during their professional working and administrative graft in extension of the handle, share information among stakeholders. They are the crucial and dominant aspects of teachers stimulating technological inclusion for the students which are used to practice in concrete and money-oriented life applications concerning on experienced and understand technology (Brok \& Schrøder, 2012; Kim et al., 2021). The significant purpose of teachers usage of stimulating technological inclusion is to apply the latest gadgets, devices and appliances among students to make an effective teaching-learning process. Teachers intermingle conventional and contemporary teaching-learning tools in the classroom (Brok \& Schrøder, 2012) to create three levels of competencies; every day, reflective and inventive (Muslimat et al., 2021). They make possible use of other parameters; comprehension, competence, critical thinking and decision making (Appavoo, 2021; Baker-Doyle, 2021). There seems the strange connection between straight and spherical observation of technological era. Institutions, programs and lectures are interlinked with regular, monotonous and progressive conduct of philosophical thoughts (Ningrum et al., 2020). Teachers work extra disintegrated and strongly influence on an institutional domain that time and restrictions are superficial (Brok \& Schrøder, 2012). Critical thinking and problemsolving, creativity and, innovations and health-related issues are teachers essential skills that significantly affect students educational success (Cheng et al., 2020; Chou et al., 2019; McGarr, 2021).

Critical thinking and problem-solving are the capability to understands, explores, evaluate, interpret and critically summarize information (Dwyer \& Walsh, 2020). Abilities focus on individuals skills regarding his/her practical reasoning, arousing new questions and answers of their solutions, analyze and evaluate substituent viewpoint and give a critical reflection of decisions and procedures (Almerich et al., 2021; Ningrum et al., 2020). Critical thinking and problem-solving skills of the 21st Century individuals are the usabilities of innovative technologies for access, manipulate, create, analyze, manage, store and communicate information (Haryani et al., 2021; Herdianto \& Indriati, 2020). Humans have the potential to emphasize on their logical reasoning, the systematic procedure of system thinking, judge, decide and problem-solving abilities (Letchumanan et al., 2020; Shkvyr et al., 2020). Teachers make proper usage of critical thinking and problem-solving skills in planning, conducting research projects, problem solving and making conclusions (Febrianto et al., 2021). They do it while using suitable technological devices and resources (Avcu \& Er, 2020; Bhambhani, 2020; Djamas \& Tinedi, 2021; Sulisworo et al., 2020).

Education sectors are continuously adapting rapid shift of creativity and innovation in the 21 st Century (Papadakis, 2016). Creativity is hidden potential that fosters thoughts, understandings and cognitive abilities with time. It is increased by proper applications of using data through innovative and informative research that promote individuals critical thinking and creative skills (Wongwuttiwat \& Winley, 2020). There is an interconnection among technological devices, learning and creativity. Technological inclusion in the account of creativity and innovation allows teachers to produce a vast value of work that provides opportunities for effective/practical learning (Fitria \& Suminah, 2020). Creativity and innovations are cultivated by inspiring mutual discussion, openness towards innovative ideas and learning 
through faults and failures (Cheng et al., 2020). The ability of creativity and innovation are ripening among teachers as other abilities and practices (Chou et al., 2019). The abilities of teachers creativity and innovation, and construction of knowledge foster their innovative products and procedure using stimulating technological inclusion (Blum-Ross et al., 2019). It is problematic to measure one's creativity, whereas there are a diversity of instruments that measure creativity and innovation, design, and problem solving (Hernandez-de-Menendez \& Morales-Menendez, 2019). Lack of devotion in fostering one's creative and innovative capabilities is due to misconceptions that arty with unambiguous digital creation. This type of art is by birth or not (Fiorini, 2018; Nikolopoulou, 2018; Prendes-Espinosa et al., 2021; RodriguezAbitia \& Bribiesca-Correa, 2021; Sofwan et al., 2021).

Power to judge technological inclusion come closer to every learner focusing health-issues. It needs to be drawn out authorized and ethical codes for freely reachable materials (Deserno et al., 2021). Teachers make legal access to resources, issues and challenges that societies face are the part of the curriculum that motivates teachers to help and develop effective communication for discussion. Health issues need to address appropriately (Sittig \& Singh, 2010). Screens, mouse and keyboards need proper support so that anyone can make their proper usage for educational purpose. Teachers have to focus on all the parts of body, particularly the fingers and backbone (Janaki \& Sunanda, 2018). During teaching, the teachers concentrate on social and health-related issues, and emphasize the essential points: apply ethical and authorized codes of practices that include esteem of intellectual belongings (Yen et al., 2017), always use official document to make discussion on technological gadgets and always make proper planning/arrangements of the seating plan, sound, light, electrical signals and noise sources (Lamb et al., 2021; Leung et al., 2015; Manojlovich et al., 2015; Sharma, 2021) that put good/worst affect on human health.

\section{Statement of the Problem}

The Government of Pakistan is showing its immense intensions towards information technology for the last decades (Government of Pakistan, 2009). Committed, dedicated and renowned stakeholders are playing their enormous role in strengthening the technology sector. Government develops policies, formulates plans, forms curriculum and invests billions of rupees in flourishing the technology sector in this regard (Government of Pakistan, 2010). Furthermore, Government maximizes its potential to strengthen teachers technological skills working in educational institutions to impart knowledge (Government of Pakistan, 2007). Stakeholders are continuously taking the pain to introduce and implement applications of stimulating technological inclusion in the curriculum from grassroots levels. After ensuring their knowledge, skills and behaviours on stimulating technological inclusion, teachers transfer this expertise among students to make them technological literate in obtaining better educational gains (Hassan \& Akbar, 2020). Focusing on the worth of technological advancement, the present quantitative ex post facto study leading to positivists paradigm was framed to measure the effect of teachers stimulating technological inclusion on university students' educational gains. The purpose of current research was to explore actual practice happening among male and female teachers working in public and private universities working under the constituency of District Lahore, Punjab province of Pakistan.

\section{Research Questions}

The following questions were addressed in this research

1. Is there any effect of teachers technological inclusion on university students educational gains?

2. What is the influence of technological inclusion factors on university students educational gains?

3. To what extent male and female teachers used their technological inclusion in acquiring public and private sector university students educational gains?

\section{METHODOLOGY AND PROCEDURE}

The research methodology is an essential aspect of the study. Researchers used to plan in exploring burning dilemmas. They are considered systematic approaches to resolve existing fact exist in institutions (Coe et al., 2021; Cohen et al., 2018; Thomas, 2021). The current study was causal-comparative, and researchers adopted an ex post facto study design that confirms the effect of an independent variable on the dependent variable (Mertler, 2021). Quantitative studies report maximum involvement of respondents in research (Saldaña, 2021), focusing extensive collection of participants (Zina, 2021) and a well-defined group of things/respondents with similar characteristics (Johnson \& Christensen, 2019).

\section{The Population of the Research}

The quantitative studies report maximum involvement of large number of objects in a research process (Boudah, 2019; Babbies, 2020). They have no set criterions of population specification (Coe et al., 2021; Silber-Varod et al., 2019). The population of the research consists of geographical location, age, gender, occupation, religious and ethnic group of the participants (Banerjee et al., 2007). The population of the research is groups of individuals from the researchers collect required information (McKenney \& Reeves, 2021). There is no need to describe healthy description of objects in study (Hennik et al., 2020; Houser, 2019; Zyphur \& Pierides, 2020). The population of current research consisted of 5,789 participants categorized in two-part: Part A: 1,789 university teachers and Part B: 4,000 master-level university students enrolled in the subject of education from 6-public and 14-private sector universities of District, Lahore (Ameen, 2007; Hassan \& Akbar, 2020; Pakistan Education Statistics, 2018) province-Punjab of Pakistan. 


\section{The Sample of the Research}

The sample is to part of research selected the from the population (Cohen et al., 2018), having an unprejudiced number of observations (Mertler, 2021), applicable in different research settings (Coe et al., 2021; Giddens \& Sutton, 2021; Hennink et al., 2020; Stockemer, 2019), having well-defined characteristics of the entire population (Christensen et al., 2015) and have the potential to generalized the research results (Besley, 2019; Johnson \& Christensen, 2019; SilberVarod et al., 2019). The sample of the research consisted of 600 respondents; 300 teachers and 300 students selected through applying Cochran (1977) and Yamane (1967) sample size calculating formula, already justified/use in other studies (Bartlett et al., 2001; Dell et al., 2002; Singh \& Masuku, 2014).

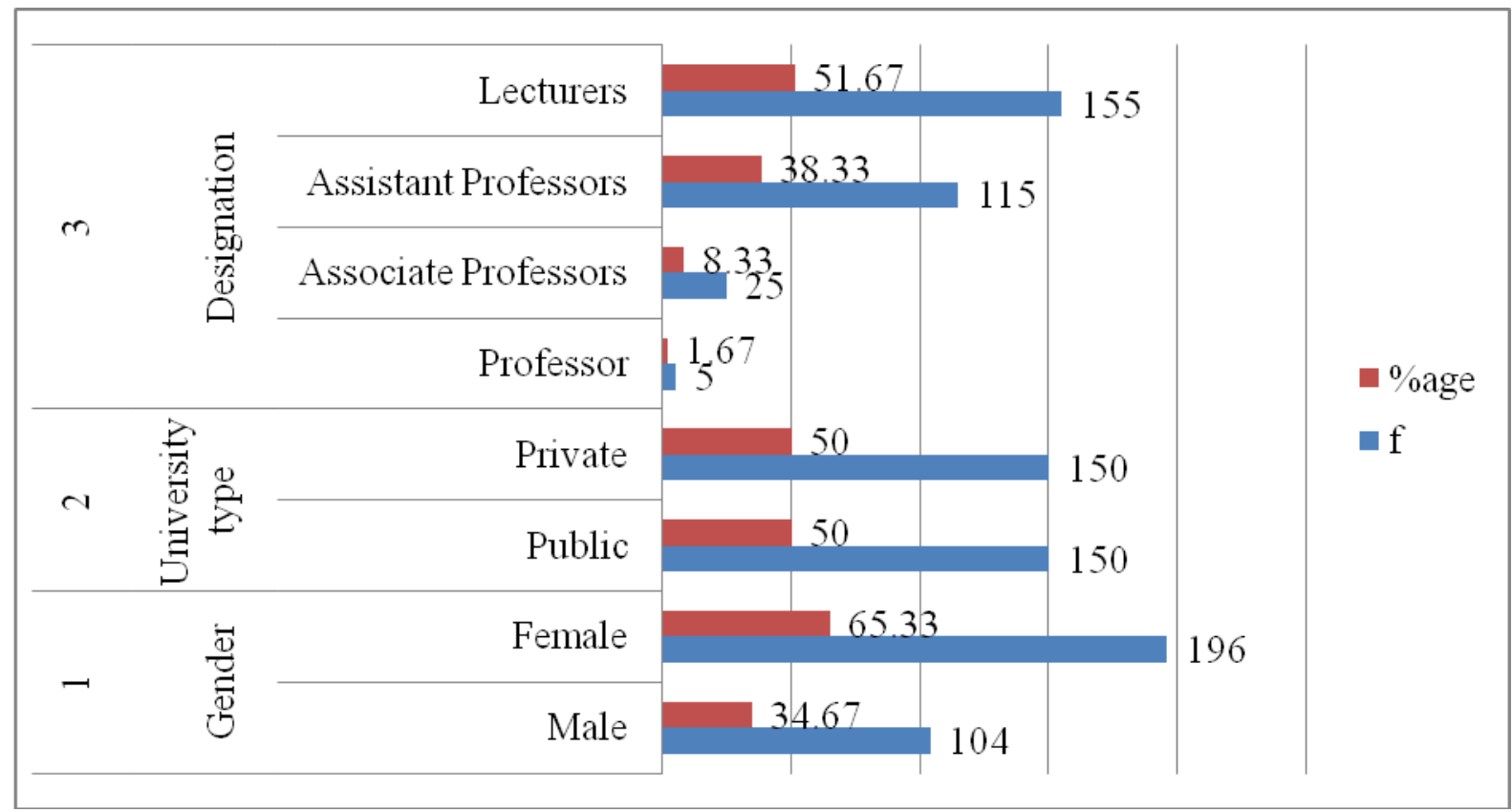

Figure 1: The sample of selected teachers

As ascertained in Figure 1, the researchers selected overall sample of 300 university teachers from every department of education working in Public and private university of District Lahore of Punjab. The majorities, in sample of university teachers are working as lecturers and assistant professors because, in Pakistani public and private universities, Associate Professors and Professors have more job responsibilities, working as heads of the institutions, remain busy in arranging workshops, organizing meetings and engaged with B.Ed (Hons), BS (Hons), B.S.Ed, M.A, M.Phil/MS and PhD students in conducting research work towards a better quality of education (Arshad, 2003; Ashraf et al., 2015; Iqbal, 2004; Hamidullah, 2004; Rehman et al., 2009; Usman, 2014). Professors are playing their catalytic role in identifying students deradicalising potential for their educational success. Due to professors demanding schedule and less availability, the researchers hardly get access on associate professors and professors to get questionnaire fill in.

The second part of the research sample consisted of 300 students randomly selected from the subject of education. The researchers focused on master-level students as they are being taught by university lecturers, assistant professors, associate professors and professors. Moreover, in some universities, there is a lack of M. Phil and PhD students (Higher Education Commission, 2005a). There are working 6-public and 14-private universities where 4,000 students are enrolled in MA education. University cadre assistant professors, associate professors and professors teach master, M. Phil and PhD level students whereas, the lectures teach only master-level students (Higher Education Commission, $\underline{2005 d}$ ). After passing MA education, students enthusiastically get admission in graduate classes, but gangs of hurdles tackle their academic life; hectic job, less availability of time, marriages and furlong areas. Resultantly, students left/freeze semesters, disappeared from exams and completed their degree more than the prescribed time.

\section{Instrumentation}

Researchers collected data from teachers after administering self-constructed questionnaire categorized in three subscales; critical thinking and problem-solving 13-items, creativity and innovations 11-items, and health-issues consisted of 9-items. The initial questionnaire consisted of 36-items mode of 5-point Likert type options. The researchers validated self-constructed questionnaire by the experts for content validity. The experts have vast experience in pedagogy, andragogy, the curriculum studies, language teaching, and management. The experts omitted 3-items that were beyond contextual settings. A self-constructed questionnaire was designed to be filled by respondents without researchers interventions, focuses on format and flexibility of items, low cost, cover anonymity and bias of researchers and traceable assenter especially when topic has sensitive and cheapest methods of collecting unsusceptible information. At the same time, the researchers comprehensively understand respondents cognitive level. It also spotlights respondents cultural 
variations, capture accurate information, easily filter, screen and measure responders rate of reaction, incorporate effective preventions during typing and formatting errors and less chance of measuring inaccuracies (Bird, 2009; Kazi \& Khalid, 2012; Lavrakas, 2008). The researchers administered validate questionnaire among male and female teachers working in public and private universities of district Lahore. University teachers impart instructions, allocate tasks, conduct activities, assign presentations and evaluate their students performance based on final semester results (Higher Education Commission, 2019). At the end of the second semester, the department conducts exams and preserved students educational gains in concerned campus/department offices. The researcher wrote consent letter to heads of institutions, explained the purpose of the study, wrote contact number, received/make telephonic calls and fix day and time for data collection. On the prescribed day, the researcher visited the concerned university office, met with the official, find the award list, randomly selected 15-students and obtained MA education students educational gains from 6-public and 14-private sector universities. The researcher collected the data from the respondents ensuring ethical considerations; informed consent, participants dignity, privacy, anonymity, privacy, no physical and psychological harm in case of participants volunteer contribution (Conway, 2021; Eriksen et al., 2021; Hoverd et al., 2021; Johnson \& Christensen, 2019; Larsson et al., 2021; Lamb et al., 2021; Nguyen, 2021; Mertler, 2021). The final questionnaire consisted of 33-items that were piloted on respondents, to ensure reliability statistics given below.

Table 1: Reliability statistics

\begin{tabular}{llll}
\hline No & Factors name & Cronbach's Alpha & Nof items \\
\hline 1 & Critical thinking and problem-solving & .821 & 13 \\
\hline 2 & Creativity and innovation & .794 & 11 \\
\hline 3 & Health-issues & .754 & 9 \\
\hline
\end{tabular}

As delineated in Table 1, the researchers calculated factor wise Cronbach's Alpha reliability statistics on approximately 10-30\% sample of the research to ensure instruments reliability (Hertzog, 2008; Johanson \& Brooks, 2010; Van Belle, 2011). The pilot studies provide/forecast/predict instrument success/failure towards the research ending process and ensure practicality and possibility of the instrument (Debbag et al., 2021; Lee \& Wessol, 2021). The researchers entered the collected data in SPSS to confirm normality;

Table 2: Tests of normality

\begin{tabular}{llcccccc}
\hline \multirow{2}{*}{ No } & \multirow{2}{*}{ Name of variables } & \multicolumn{3}{c}{ Kolmogorov-Smirnov ${ }^{\boldsymbol{a}}$} & \multicolumn{2}{l}{ Shapiro-Wilk's } \\
\cline { 3 - 8 } & & $\boldsymbol{K}-\boldsymbol{S}$ & $\boldsymbol{d f}$ & $\boldsymbol{P}$ & $\boldsymbol{S}-\boldsymbol{W}$ & $\boldsymbol{d f}$ & $\boldsymbol{P}$ \\
\hline 1 & Students educational gains & .140 & 300 & .01 & .913 & 300 & .32 \\
\hline 2 & Critical thinking and problem-solving & .211 & 300 & .01 & .861 & 300 & .51 \\
\hline 3 & Creativity and innovation & .139 & 300 & .01 & .947 & 300 & .20 \\
\hline 4 & Health-issues & .146 & 300 & .01 & .943 & 300 & .10 \\
\hline a. Significance Correction & & & & & &
\end{tabular}

As declared in Table 2, the authors applied Shapiro-Wilk's test to determine the normality of the data that assist researchers in applying/choosing parametric and non-parametric statistical techniques (Lorah \& Valdivia, 2021; Utts \& Heckard, 2021). The literature reported that Shapiro-Wilk's test with statistical value $n\langle 2000, p\rangle .05$ is appropriate test to determine the normality of the data (Fillon et al., 2021; Ho \& Yu, 2015; Mishra et al., 2019; Song \& Zhao, 2021) for applying regression analysis technique to explore cause and effect relationship among/between variables (Abu-Bader, 2021; Hardin, et al., 2021; Hu \& Plonsky, 2021; Huang, 2021; Terrell, 2021; Van Truong \& Huyen, 2021).

\section{DATA ANALYSIS AND INTERPRETATION}

This part improvised data analysis and interpretation. Data were analyzed applying independent samples t-test and regression analysis techniques. The literature revealed that teachers technological literacy interplay as independent variables (Hassan \& Akbar, 2020; Jackson et al., 2011; Leung \& Lee, 2012), whereas students educational gains are manipulated as dependent variables (Amina, 2016; Harris et al., 2016; Wenglinsky, 2005).

Table 3: Effect of teachers stimulating technological inclusion on university students educational gains

\begin{tabular}{llccccc}
\hline No & Model & $\boldsymbol{B}$ & $\boldsymbol{S E}$ & $\boldsymbol{B}$ & $\boldsymbol{t}$ & $\boldsymbol{p}$ \\
\hline \multirow{2}{*}{1} & (Constant) SEG & 336.500 & .761 & & 442.140 & .01 \\
\cline { 2 - 7 } & Teachers technological inclusion & .307 & .012 & .829 & 25.581 & .01 \\
\hline
\end{tabular}

$R=.829^{\mathrm{a}}, R^{2}=.687 ;\left(F(1,299)=654.397, p<.05^{\mathrm{a}}\right)$

As presented in Table 3, the authors run a simple linear regression to explore the effect of teachers stimulating technological inclusion on students educational gains that ascertained construction of significant equation $(F(1,299)=$ 654.397, $p<.01$ ) having .687 value of $\mathrm{R}^{2}$ with $68.70 \%$ explained variations were seen with standardized regression coefficient $(\beta=.829)$. Reporting the results of the regression coefficient, the interpretation of an independent sample ttest portrayed that teachers stimulating technological inclusion were significant predictor on students educational gains, $t(298)=25.581, p<.01$. The university students predicted educational gains increased $336.500+.307$ scores where 
teachers stimulating technological inclusion were measured through teachers technological potential applied in classrooms. It is concluded that students educational gains raised .307 scores by using teachers technological inclusion on students for their better didactic achievements.

Table 4: Factors of teachers technological inclusion effecting on university students educational gains

\begin{tabular}{lcccccccc}
\hline Model & $\boldsymbol{F}$ & $\boldsymbol{R}$ & $\boldsymbol{R}^{2}$ & $\boldsymbol{B}$ & $\boldsymbol{S E}$ & $\boldsymbol{\beta}$ & $\boldsymbol{t}$ & $\boldsymbol{p}$ \\
\hline (Constant) SEG & & & & 1255.478 & 63.756 & & 19.692 & .01 \\
\hline Critical thinking and problem-solving & 654.168 & $.818^{\mathrm{a}}$ & .667 & .860 & .034 & .818 & 25.581 & .01 \\
\hline Creativity and innovation & 643.467 & $.827^{\mathrm{a}}$ & .687 & 1.075 & .042 & .827 & 25.581 & .01 \\
\hline Health-issues & 665.294 & $.797^{\mathrm{a}}$ & .690 & .860 & .034 & .797 & 25.581 & .01 \\
\hline
\end{tabular}

Note: $R=.814^{\mathrm{a}}, R^{2}=.681, \beta=.814 ;\left(F(3,297)=654.310, p<.05^{\mathrm{a}}\right)$

As revealed in table 4, the researchers applied multiple linear regression that ascertained factors overall .681 value of $\mathrm{R}^{2}$ having $68.10 \%$ increased variations were observed with the construction of a significant equation $(F(3,297)=654.310$, $p<.01)$ with regression coefficient $(\beta=.814)$. The results further yielded formation of a significant equation in favor of: critical thinking and problem-solving $(F(1,299)=654.168, p<.01)$ having .667 value of $R^{2}$ with $66.70 \%$ increased variances were observed with regression coefficient $(\beta=.818)$; creativity and innovation, $(F(1,299)=643.467, p<.01)$ having .687 value of $\mathrm{R}^{2}$ with $68.70 \%$ increased variance were seen with regression coefficient $(\beta=.827)$ and healthissues, $(F(1,299)=665.294, p<.01)$ having .690 value of $\mathrm{R}^{2}$ with $69.10 \%$ increased variance were noted through regression coefficient $(\beta=.797)$. Reflecting output of significant regression coefficient, explanation of independent sample t-test ascertained that teachers stimulating technological inclusion in favor of critical thinking and problemsolving, $t(298)=25.581, p<.01$; creativity and innovations, $t(298)=25.581, p<.01$ and health issues, $t(298)=25.581$, $p<.01$ were significant predictors on students educational gains. University students estimated achievements were equal to $1225.478+.860+1.075+.860$ scores whereas teachers stimulating technological inclusions were measured through acquiring educational gains obtained in the classroom. It is concluded that students educational gains were increased 2.80 scores by applying teachers critical thinking and problem-solving, creativity and innovations and health-issues for the sake of students educational gains.

Table 5: Independent sample t-test on teachers gender and university type

\begin{tabular}{lllccccc}
\hline \multirow{2}{*}{ No. } & Variables & $\boldsymbol{N}$ & $\boldsymbol{M}$ & $\boldsymbol{S D}$ & $\boldsymbol{d} \boldsymbol{f}$ & $\boldsymbol{t}$ & $\boldsymbol{P}$ \\
\hline \multirow{2}{*}{1} & \multirow{2}{*}{ Teachers gender } & Male & 35.00 & 27.44 & \multirow{2}{*}{298} & 13.94 & \multirow{2}{*}{.01} \\
\cline { 3 - 8 } & & Female & 29.89 & 34.77 & & & \\
\hline \multirow{2}{*}{2} & \multirow{2}{*}{ University type } & Public & 31.20 & 42.15 & \multirow{2}{*}{298} & 10.642 & .01 \\
\cline { 3 - 8 } & & Private & 35.26 & 20.10 & & \\
\hline
\end{tabular}

As established in Table 5, authors applied independent samples t-test to compare male and female university teachers stimulating technological inclusion for students educational gains enrolled in public and private universities. Interpretation established significant difference between university teachers stimulating technological inclusion by their gender, $t(298)=13.94, p<.05$; male teachers were more stimulating technological inclusion $(M=350.02, S D=27.44)$ as compared to female teachers $(M=298.98, S D=34.77)$ and university type, $t(298)=10.642, p<.05$; private sector university teachers were more stimulating technological inclusion $(M=352.61, S D=20.10)$ as compared to public sector university teachers $(M=312.04, S D=42.15)$ for obtaining students better educational gains.

Table 6: T-test on factors of technological inclusion by teachers gender and university type

\begin{tabular}{|c|c|c|c|c|c|c|c|c|c|}
\hline No. & Factors & \multicolumn{2}{|c|}{ Variables } & $N$ & $M$ & $S D$ & $d f$ & $t$ & $p$ \\
\hline \multirow{2}{*}{1} & \multirow{2}{*}{ Critical thinkin } & \multirow{6}{*}{ 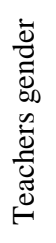 } & Male & 104 & 59.308 & .592 & \multirow{2}{*}{298} & \multirow{2}{*}{29.58} & \multirow{2}{*}{.01} \\
\hline & & & Female & 196 & 56.510 & .862 & & & \\
\hline \multirow{2}{*}{2} & \multirow{2}{*}{ Creativity and innovations } & & Male & 104 & 59.712 & .900 & \multirow{2}{*}{298} & \multirow{2}{*}{17.27} & \multirow{2}{*}{.01} \\
\hline & & & Female & 196 & 56.597 & 1.717 & & & \\
\hline \multirow{2}{*}{3} & \multirow{2}{*}{ Health-issues } & & Male & 104 & 31.413 & 1.498 & \multirow{2}{*}{298} & \multirow{2}{*}{10.61} & \multirow{2}{*}{.24} \\
\hline & & & Female & 196 & 29.439 & 1.553 & & & \\
\hline \multirow{2}{*}{4} & \multirow{2}{*}{ Critical thinking and problem-solving } & & Public & 150 & 58.653 & 1.300 & \multirow{2}{*}{98} & \multirow{2}{*}{20.26} & \multirow{2}{*}{.01} \\
\hline & & $\sum_{3}^{2}$ & Private & 150 & 56.307 & .567 & & & \\
\hline \multirow{2}{*}{5} & \multirow{2}{*}{ Creativity and innovations } & $\geqq$ & Public & 150 & 59.280 & 1.221 & \multirow{2}{*}{298} & \multirow{2}{*}{20.51} & \multirow{2}{*}{.14} \\
\hline & & $\frac{n}{2}$ & Private & 150 & 56.073 & 1.475 & & & \\
\hline \multirow{2}{*}{6} & \multirow{2}{*}{ Health-issues } & 光 & Public & 150 & 31.107 & 1.410 & \multirow{2}{*}{298} & \multirow{2}{*}{11.31} & \multirow{2}{*}{.47} \\
\hline & & & Private & 150 & 29.140 & 1.597 & & & \\
\hline
\end{tabular}

As ascertained in Table 6, the researchers used independent sample t-test to compare gender wise teachers stimulating technological inclusion working in public and private sector universities. Interpretation yielded significant difference between male and female teachers technological inclusion on factors regarding: critical thinking and problem solving, 
$t(298)=29.58, p<.01$; male teachers were more critical thinkers and problem solvers $(M=59.308, S D=.592)$ as compared to female teachers $(M=56.510, S D=.862)$; creativity and innovations, $t(298)=17.27, p<.01$; male teachers were more creative and innovators $(M=59.712, S D=.900)$ as compared to female teachers $(M=56.597, S D=1.717)$ and found no significant difference between male and female teachers health issues, $t(298)=10.61, p<.01$; male teachers were same conscious $(M=31.413, S D=1.498)$ about health issues as compared to female teachers $(M=$ $29.439, S D=1.553)$. Interpretation further revealed significant difference between teachers working in public and private sector universities regarding: critical thinking and problem solving, $t(298)=20.26, p<.01$; public sector university teachers were more critical thinkers and problem solvers $(M=58.653, S D=1.300)$ as compared to private university teachers $(M=56.307, S D=.567)$, found no significant difference between public and private universities teachers creativity and innovations, $t(298)=20.51, p>.01$; public sector universities teachers were same creative and innovators $(M=59.280, S D=1.221)$ as compared to private sector universities teachers $(M=56.073, S D=1.475)$ and also found no significant difference between teachers university type and health issues, $t(298)=11.31, p>.05$; public sector universities teachers were same aware about health issues $(M=31.107, S D=1.410)$ as well as private sector universities teachers $(M=29.140, S D=1.597)$.

\section{DISCUSSION}

Teachers are indispensable assets in educated world who play an essential role in making students skilled and technologically literate. They inspire students intentions through utilizing available resources towards dissemination digital knowledge (Sack-Min, 2007). Teachers evaluate students knowledge with the intention of rearrange, systematize and, estimation of scientific facts as well (Lu et al., 2021). In educational institutions, teachers use different technologies; Google, Whatsapp, Facebook, Twitter, Instagram, YouTube, Wikis, multimedia, Projector and, Zoom among students for their effective learning (Barrot, 2021; Eaton et al., 2021; Holloway et al., 2021; Jabbar et al., 2021; Rosenberg \& Asterhan, 2018; Sutherland et al., 2004). These influential and consequential technologies interlink the learner in the dynamic and vigorous teaching-learning process and obviously, set aside the teacher to share the knowledge of humankind with their classroom. These technologies optimistically manipulate teacher learning, high order philosophy of thought and judgment (Rossouw et al., 2011). Teachers regulate and operate these components to make teaching effective. Research in teachers stimulating technological inclusion and its effect on their teaching is the beginning of the new field, but it has presented a remarkable development (Hassan \& Akbar, 2020; Roussou, 2004). Findings of the current research revealed that teachers technological inclusion put $33.20 \%$ affect on students educational gains that support with the results of the quantitative study conducted by Leung and Lee (2012) on a sample of 718 male and female students in Hong Kong to examine the impact of technological inclusion, the symptom of internet addiction and activities on students educational gains, whose results ascertained significant relationship between technological/internet inclusion and students educational gains, $\left(r=.11^{* *}, n=716, p<.05\right)$ also similar with the findings of present research whose results declared that male teachers were more stimulating technological inclusion $(M=350.02, S D=27.44)$ as compared to female teachers $(M=298.98, S D=34.77)$. Results further declared an overall significant relationship; value ranged between five dimensions and students educational gains, $\left(r=.09^{* * *}\right.$ to $\left..27^{* *}, n=716, p<.01\right)$ that strongly consonance with the findings of the current study and also congruent with the results of quantitative research structured by Wentworth and Middleton (2014) structured to explore the impact of teachers stimulating technological inclusion on students educational gains on a sample of 483 respondents selected from private sector University of USA. The researchers selected those students who were voluntary participated in research with gender, age, class level and job status. The researchers collected the data through administering close-ended responses statements applying survey technique criteria put forwarded by Church and Waclawski (1998) based on transparency, relevancy and specificity. The authors obtained Biology and Psychology students educational gains from concerned university office. The results of one Way ANOVA ascertained that teachers stimulating technical inclusion affect $16 \%$ on students educational gains with formation of significant regression equation $(F(2,129)=13.51, p<.05)$ Findings further confirm significant consequences of gender and employment on students educational gains $(F(3,119)=8.33, p<.01)$. Teachers are stimulating technical inclusion play an imperative role in students educational and professional success. Teachers technical skills are predictable to simplify the affect on their teaching. Natural behaviours and the visual environment are essential components that affect on teachers technical inclusion (Roussou, 2004; Wins \& Jackson, 1999). The findings of the current research congruent with the results of the study conducted by Judge (2005) to explore the impact of teachers technical skills on students educational gains on a sample of 1,061 African American students. The researchers collected the data from teachers through a questionnaire based on technical access and competence of resources mode of 4-point Likert type options. The authors obtained students mathematics and reading assessment scores based on the applications of Item Response Theory practised in the normal classrooms. The results of parametric statistics declared a significant difference between teachers technical inclusion and students writing gains $(F(2,998)=9.24, p<.01)$ and reading educational gains $(F(2,999)=3.12, p<.01)$. The results of the current research also supported with the findings of the quantitative research structured by Hassan and Akbar (2020) in Pakistan to find out the influence of teachers technical inclusion on students educational gains on a sample of 200 participants, administering the self-constructed questionnaire, whereas the authors obtained students educational gains from concerned university offices after ensuring ethical considerations. The results ascertained that overall teachers technical inclusion affect $48 \%$ of students educational gains with the formation of a significant regression equation, $(\mathrm{F}(1,199=9.970, p<.05)$. Teachers impart instructions, share experiences and produce skilled students to make the country developed. Teachers less use of skills lead students 
towards declining level. Race of students better educational career, technical innovation, ones worth, earning own name, and individuals recognition strengthens students technical potential. Resultantly continuous usage of technical knowledge enables students to cope with innovative trends. Like other countries, discrepancies in Pakistan educational institutions are going to be overcome through hiring qualified staff, conducting workshops, and seminars.

\section{CONCLUSIONS}

The world is changing gradually. This change is due to the enhancement of technology in every walk of life. Applications of teachers stimulating technical inclusion put long-lasting effects on individuals entire existence towards fruitful results. Human beings are familiar with their responsibilities when they are indulged in their cell phones, laptops, the internet and other digital media. The handiness of technical gadgets among the individuals creates a better quality of peers facilitation and collectively endeavours everywhere. University teachers are providing their services in public and private sector universities having the same qualifications and vary in their teaching experiences. They possess academic and professional knowledge and impart their pedagogical and technical in successive generations. However, they differ in their stimulating technical inclusion. The current research was framed in Lahore to determine the effect of male and teachers technological inclusion working in public and private sector universities on students educational gains on a sample of randomly 600 respondents. The authors administered a self-constructed questionnaire after ensuring its content validity and calculating Cronbach's Alpha reliability statistics; .856. The researchers obtained students educational gains from public and private university office, after securing ethical considerations. The researchers run regression analysis and independent sample t-test on collected data. The results of the present research declared that university teachers overall $31.3 \%$ were lack in their stimulating technical inclusion. However, they have a significant concern for students educational gains, whereas university teachers remain familiar with their students personal, educational and social problems. They motivate students for success, impart more instructions and skill them with more technical gadgets. It is further concluded that teachers were $33.3 \%$ weak in critical thinking and problem-solving, with a reduction of $31.3 \%$ in creativity and innovation and $30.9 \%$ pathetic in health-issues used in university teachers for the sake of students better educational gains. It is one of the facts that less applicability of teachers stimulating technical inclusion loose students interest in getting better educational improvements in exams. The students become mindnumbing, absconder and freeze their cognitive abilities. The present study concludes that male teachers possess more technical knowledge as compared to female teachers. Male teachers always remained the dominant part of Pakistani societies because they have more social relations, easy to travel and try their best to learn more as compared to females. Male teachers have to take part in technical related workshops and are eager towards technological advancements as compared to female teachers. Teachers working in private sector universities have more stimulating technological potential, skilled in using technological gadgets than teachers working in public sector universities. Private sector University teachers have to work hard to secure their jobs, obtain more incentives and acquire extra benefits. Pakistani university teachers working in public sector universities on a regular basis are claimed as dancing emperor of institutions and less focused on their jobs, incentives. They have firm beliefs that now we are in safe hands, and no authority is capable of firing us from jobs. Resultantly, they less concentrates on their students technical inclusion that leads students towards poor achievements. It is one of the reasons that students enrollments in public sector universities are going down. Teachers put their maximum technical potential among students for their better educational and professional success. Furthermore, they become lethargic, less cooperative and unable to take part in classroom discussion. They may have fewer social interactions with societies. The overall study concludes that teachers stimulating technical tools are essential aspects that significantly affect on teachers technological skills including students entire life career.

\section{LIMITATIONS AND RESEARCH FORWARD}

Applications of technological appliances in schools unlock teachers and students buried potential. It focuses on availing present resources available for students present-day needs. This research was limited to public and private universities of District Lahore Punjab province of Pakistan. This research will open the ways to conduct researchers on Sindh, Balochistan, Gilgit Baltistan, including Azad Jimmu and Kashmir-Pakistan, where public and private sector universities are also working in which teachers are providing their services to enhance university students technological learning. The researchers limited current research on quantitative leading to positivists research paradigm while future researchers may apply the qualitative and mixed-method design on the same constructs.

\section{AUTHORS CONTRIBUTIONS}

The authors have significantly contributed by performing various errands in this research. Dr. Mehboob Ul Hassan presented the research idea, addressed research questions, highlighted key aspects of the research methodology, sequentially ran analysis and, logically interpreted the research results. He critically formulated discussion part and wrote conclusions. He generated hyperlink of citations with the end references. Furthermore, he incorporated all necessary changes suggested by the reviewer(s). Dr. Haq Nawaz entered the collected data in SPSS, wrote abstract, introduction and checked all references with prescribed journal format (APA 7th edition). He enthusiastically worked on references part with true spirit and vigor. Dr. Abu Ul Hassan Faiz did hectic job in writing literature review and analytically wrote future implications of the research in this regards. He collected the data from the public and private sector universities of District Lahore. In short, all three authors drastically contributed to completing this research paper. 


\section{REFERENCES}

1. Abu-Bader, S. H. (2021). Using statistical methods in social science research: With a complete SPSS guide. Oxford University Press, USA.

2. Adarkwah, M. A. (2021). I'm not against online teaching, but what about us? ICT in Ghana post Covid19. Education and Information Technologies, 26(2), 1665-1685. https://doi.org/10.1007/s10639-020-10331-Z

3. Almerich, G., Suárez-Rodríguez, J., Díaz-García, I., \& Cebrián-Cifuentes, S. (2020). 21st-century competences: The relation of ICT competences with higher-order thinking capacities and teamwork competences in university students. Journal of Computer Assisted Learning, 36(4), 468-479. https://doi.org/10.1111/jcal.12413

4. Ameen, K. (2007, August). Issues of quality assurance (QA) in LIS higher education in Pakistan, paper presented in World library and information congress, Durban, South Africa.

5. Amina, A. M. (2016). Self-concept, locus of control and school motivation in relation to academic achievement among secondary school students in northern Nigeria published doctoral dissertation, school of education, university of Leicester, England, UK.

6. Andersson, S. B. (2006). Newly qualified teachers' learning related to their use of information and communication technology: A Swedish perspective. British Journal of Educational Technology, 37(5), 665682. https://doi.org/10.1111/j.1467-8535.2006.00563.x

7. Appavoo, P. (2021). Acceptance of technology in the classroom: A qualitative analysis of mathematics teachers' perceptions. In Intelligent System Design (pp. 1-10). Springer, Singapore.

8. Arshad, M. (2003). Attitude of teachers of higher education toward their profession. Unpublished master of philosophy dissertation, department of teachers education, Allama Iqbal Open University, Islamabad, Pakistan.

9. Ashraf, I., Ashraf, F., Saeed, I., Shah, K., Azhar, N., Anam, W. (2015). Teachers' performance problems in higher education institutions of Pakistan. Journal of Academic Research in Progressive Education and Development, 4(3), 24-45. https://doi.org/10.6007/IJARPED/v4-i3/1769

10. Avcu, Y. E., \& Er, K. O. (2020). Developing an instructional design for the field of ICT and software for gifted and talented students. International Journal of Educational Methodology, 6(1), 161-183.

11. Babbie, E. R. (2020). The practice of social research. Cengage learning.

12. Baker-Doyle, K. J. (2021). Transformative teachers: Teacher leadership and learning in a connected world. Harvard Education Press.

13. Banerjee, A., Chaudhury, S., Singh, D. K., Banerjee, I., Mahato, A. K., \& Haldar, S. (2007). Statistics without tears: Population and Sample Indian. Industrial Psychiatry Journal, 16(1), 60-65.

14. Barrot, J. S. (2021). Effects of Facebook-based e-portfolio on ESL learners' writing performance. Language, Culture and Curriculum, 34(1), 95-111. https://doi.org/10.1080/07908318.2020.1745822

15. Bartlett, J. E., Kotrlik, J. W., \& Higgins, C. C. (2001). Organizational research: Determining appropriate sample size in survey research. Information Technology, Learning, and Performance Journal, 19(1), 43-50.

16. Bayaga, A., Bossé, M. J., Sevier, J., Fountain, C., Williams, D., Bosire, S., \& Blignaut, S. (2021). University faculty opinions of pre-service teachers' technological readiness. Canadian Journal of Science, Mathematics and Technology Education, 21(1), 44-64. https://doi.org/10.1007/s42330-021-00138-6

17. Bennett, S., Maton, K., \& Kervin, L. (2008). The 'digital natives' debate: A critical review of the evidence. British Journal of Educational Technology, 39(5), 775-786. https://doi.org/10.1111/j.1467-8535.2007.00793.x

18. Besley, T. A. (2019). Assessing the quality of educational research in higher education: International perspectives. Brill Publishers.

19. Bhambhani, J. (2020). Changes, innovations, and reforms in education from traditional learning to 21 st century learning. In Role of ICT in Higher Education (pp. 133-140). Apple Academic Press.

20. Bird, D. K. (2009). The use of questionnaires for acquiring information on public perception of natural hazards and risk mitigation-a review of current knowledge and practice. Natural Hazards and Earth System Sciences, 9(4), 1307-1325. https://doi.org/10.5194/nhess-9-1307-2009

21. Blum-Ross, A., Kumpulainen, K., \& Marsh, J. (2019). Enhancing digital literacy and creativity: Makerspaces in the early years. Routledge. https://doi.org/10.4324/9780429243264

22. Boettcher, J. V., \& Conrad, R. M. (2021). The online teaching survival guide: Simple and practical pedagogical tips. John Wiley \& Sons.

23. Boudah, D. J. (2019). Conducting educational research: Guide to completing a thesis, Dissertation, or action research project. Sage Publications.

24. Boulton, C. A., Kent, C., Williams, H. T. (2018). Virtual learning environment engagement and learning outcomes at a 'bricks-and-mortar' university. Computers and Education, 126(1), 129-142. https://doi.org/10 1016/j.compedu.2018.06.031

25. Brok, L. S., \& Schrøder, V. (2012). Understanding and developing “Technological literacy" through Living Labs in teacher vocational education. Retrieved from https://technucation.dk/fileadmin/www.technucatio n.dk/205237_P2 2 01.pdf

26. Chege, S. M., Wang, D., \& Suntu, S. L. (2020). Impact of information technology innovation on firm performance in Kenya. Information Technology for Development, 26(2), 316-345. https://doi.org/10.10 $\underline{80 / 02681102.2019 .1573717}$ 
27. Chou, C. M., Shen, C. H., Hsiao, H. C., \& Shen, T. C. (2019). Factors influencing teachers' innovative teaching behaviour with information and communication technology (ICT): the mediator role of organisational innovation climate. Educational Psychology, 39(1), 65-85. https://doi.org/10.1080/01443410.2018.1520201

28. Christensen, L. B., Johnson, R. B., Turner, L. A. (2015). Research methods, design, and analysis (12th ed.). Pearson.

29. Church, A., \& Waclawski, J. (1998). Designing and using organizational surveys: A seven-step process. Jossey Bass.

30. Cochran, W. G. (1977). Sampling techniques (3rd ed.). John Wiley \& Sons.

31. Coe, R., Waring, M., Hedges, L. V., \& Ashley, L. D. (2021). Research methods and methodologies in education. Sage.

32. Cohen, L., Manion, L., \& Morrison, K. (2018). Research methods in education (8th ed.). Routledge.

33. Conway, M. (2021). Online extremism and terrorism research ethics: researcher safety, informed consent, and the need for tailored guidelines. Terrorism and Political Violence, 33(2), 367-380. https://doi.org/10.1080/0 9546553.2021.1880235

34. Debbag, M., Cukurbasi, B., \& Fidan, M. (2021). Use of digital mind maps in technology education: a pilot study with pre-service science teachers. Informatics in Education, 20(1), 47-68. https://doi.org/10.15 388/infedu.2021.03

35. Dele-Ajayi, O., Fasae, O. D., \& Okoli, A. (2021). Teachers' concerns about integrating information and communication technologies in the classrooms. Plos One, 16(5), e0249703. https://doi.org/10.13 71/journal.pone.0249703

36. Dell, R. B., Holleran, S., \& Ramakrishnan, R. (2002). Sample size determination. Institute for Laboratory Animal Research Journal, 43(4), 207-213. https://doi.org/10.1093/ilar.43.4.207

37. Deserno, T. M., Dugas, M., Löbe, M., \& Stausberg, J. (2021). A topical collection on ICT for health science Research-EFMI Special topic conference. Journal of Medical Systems, 45(7), 1-5. https://doi.org/10.1 007/s10916-021-01739-2

38. Deshpande, S., \& Shesh, A. (2021). Blended learning and analysis of factors affecting the use of ICT in education. In Next Generation Information Processing System (pp. 311-324). Springer. https://doi.org/10. 1007/978-981-15-4851-2_33

39. Djamas, D., \& Tinedi, V. (2021). Development of interactive multimedia learning materials for improving critical thinking skills. In research anthology on developing critical thinking skills in students (pp. 507-525). IGI Global. https://doi.org/10.4018/978-1-7998-3022-1.ch026

40. Dong, C., \& Mertala, P. (2021). Two worlds collide: The role of Chinese traditions and Western influences in Chinese pre-service teachers' perceptions of appropriate technology use. British Journal of Educational Technology, 52(1), 288-303. https://doi.org/10.1111/bjet.12990

41. Dwyer, C. P., \& Walsh, A. (2020). An exploratory quantitative case study of critical thinking development through adult distance learning. Educational Technology Research and Development, 68(1), 17-35. https://doi.org/10.1007/s11423-019-09659-2

42. Eaton, P. W., Pasquini, L., Ahlquist, J. R., \& Gismondi, A. (2021). Student affairs professionals on Facebook: an empirical look. Journal of Student Affairs Research and Practice, 58(1), 62-78. https://doi.org/10.10 $\underline{80 / 19496591.2020 .1727343}$

43. Eriksen, H., Rautio, A., Johnson, R., Koepke, C., \& Rink, E. (2021). Ethical considerations for communitybased participatory research with Sami communities in North Finland. Ambio, 50(6), 1222-1236. https://doi.org/10.1007/s13280-020-01459-w

44. Febrianto, T., Ngabekti, S., \& Saptono, S. (2021). The effectiveness of schoology-assisted PBL-STEM to improve critical thinking ability of junior high school students. Journal of Innovative Science Education, 10(1), 222-229.

45. Fekete, I. (2021). Information and Communications Technology (ICT) literacy of Hungarian English majors: A validation study. Journal of Adult Learning, Knowledge and Innovation, 4(1), 31-39. https://doi.org/10.1 $\underline{556 / 2059.2020 .00002}$

46. Fillon, A., Kutscher, L., \& Feldman, G. (2021). Impact of past behaviour normality: meta-analysis of exceptionality effect. Cognition and Emotion, 35(1), 129-149. https://doi.org/10.1080/02699931.2020.1816910

47. Fiorini, R. A. (2018). Transdisciplinary education for deep learning, creativity and innovation. Eruditio, 2(4), 123-146.

48. Fitria, H., \& Suminah, S. (2020). Role of teachers in digital instructional era. Journal of Social Work and Science Education, 1(1), 70-77. https://doi.org/10.52690/jswse.v1i1.11

49. Fuchs, C. (2021). Social media: A critical introduction. Sage.

50. Giddens, A., \& Sutton, P. W. (2021). Essential concepts in sociology. John Wiley \& Sons.

51. Government of Pakistan. (2006). National curriculum for physics grade IX-X 2006. Islamabad: Ministry of Education.

52. Government of Pakistan. (2007). National textbook and learning materials policy and plan of action. Islamabad: Curriculum Wing, Ministry of Education.

53. Government of Pakistan. (2009). National education policy 2009. Islamabad: Ministry of Education. 
54. Government of Pakistan. (2010). A manual for curriculum development 2010. Curriculum wing, Islamabad: Ministry of Education.

55. Hamidullah, M. (2004). Comparison of the quality of higher education in public and private institutions in Pakistan, unpublished doctoral dissertation, university Institute of education and research, Pir Mehr Ali Shah, university of Arid Agriculture, Rawalpindi, Pakistan.

56. Hamilton, D., McKechnie, J., Edgerton, E., \& Wilson, C. (2021). Immersive virtual reality as a pedagogical tool in education: a systematic literature review of quantitative learning outcomes and experimental design. Journal of Computers in Education, 8(1), 1-32. https://doi.org/10.1007/s40692-020-00169-2

57. Hardin, J., Horton, N. J., Nolan, D., \& Lang, D. T. (2021). Computing in the statistics curricula: A 10-year retrospective. Journal of Statistics and Data Science Education,29(1), 4-6. https://doi.org/10.1080/ 10691898.2020 .1862609

58. Harris, J. L., Al-Bataineh, M. T., \& Al-Bataineh, A. (2016). One to one technology and its effect on student academic achievement and motivation, Contemporary Educational Technology, 7(4), 368-381. https://doi.org/1 $0.30935 /$ cedtech/6182

59. Hart, S. (1982). The perceived competence scale for children. Child Development, 53(1), 87-97. https://doi.org/10.2307/1129640

60. Haryani, E., Coben, W. W., Pleasants, B. A., \& Fetters, M. K. (2021). Analysis of teachers' resources for integrating the skills of creativity and innovation, critical thinking and problem solving, collaboration, and communication in science classrooms. Indonesian Science Education Journal, 10(1), 92-102.

61. Hassan, M. U., \& Akbar, R. A. (2020). Technological literacy: Teachers' progressive approach used for 21st century students' academic success in vibrant environment. Problems of Education in the 21st Century, 78(5), 734-753. https://doi.org/10.33225/pec/20.78.734

62. Hébert, C., Jenson, J., \& Terzopoulos, T. (2021). Access to technology is the major challenge: Teacher perspectives on barriers to DGBL in K-12 classrooms. E-Learning and Digital Media, 18(3), 307-324. https://doi.org/10.1177/2042753021995315

63. Hennink, M., Hutter, I., \& Bailey, A. (2020). Qualitative research methods. Sage.

64. Herdianto, E. N., \& Indriati, D. (2020, April). ICT-based learning media to enhance students' problem solving ability in efforts to face the industrial revolution 4.0. In Journal of Physics: Conference Series (Vol. 1511, p. 012097). IOP Publishing. https://doi.org/10.1088/1742-6596/1511/1/012097

65. Hernandez-de-Menendez, M., \& Morales-Menendez, R. (2019). Technological innovations and practices in engineering education: a review. International Journal on Interactive Design and Manufacturing, 13(2), 713728. https://doi.org/10.1007/s12008-019-00550-1

66. Hertzog, M. A. (2008). Considerations in determining sample size for pilot studies. Research in Nursing and Health, 31(2), 180-191. https://doi.org/10.1002/nur.20247

67. Higher Education Commission (2005a). Higher Education Commission Programme and initiatives. Islamabad, Pakistan.

68. Higher Education Commission (2005d). Statistical booklet on higher education of Pakistan. HEC Islamabad.

69. Higher Education Commission, (2019). Higher Education Development Program (HEDP) Environmental and Social Management Framework (ESMF), Higher Education Commission, Government of Pakistan.

70. Ho, A. D., \& Yu, C. C. (2015). Descriptive statistics for modern test score distributions: Skewness, kurtosis, discreteness, and ceiling effects. Educational and Psychological Measurement, 75(3), 365-388. https://doi.org/10.1177/0013164414548576

71. Holloway, J. A., Johnsen, D. C., \& Syrbu, J. (2021). Student performance comparisons for a critical thinking skill set (technology decision-making) for classroom and remote (Zoom) facilitation. Journal of Dental Education, 85(3), 379-382. https://doi.org/10.1002/jdd.12443

72. Houser, R. A. (2019). Counseling and educational research: Evaluation and application. Sage Publications.

73. Hoverd, E., Staniszewska, S., \& Dale, J. (2021). The informed consent process in health research with underserved populations: a realist review protocol. Systematic Reviews, 10(1), 1-9. https://doi.org/10.1186/s13643021-01652-2

74. Hu, Y., \& Plonsky, L. (2021). Statistical assumptions in L2 research: A systematic review. Second Language Research, 37(1), 171-184. https://doi.org/10.1177/0267658319877433

75. Huang, H. (2021). Analysis on teaching effectiveness of primary mathematics teachers based on SPSS. International Journal of Social Science and Education Research, 4(4), 256-263.

76. International Technology Education Association. (2000). Standards for technological literacy: Content for the study of technology: Author.

77. Iqbal, A. (2004). Problems and prospects of higher education, unpublished doctoral dissertation, university Institute of education and research, Pir Mehr Ali Shah, University of Arid Agriculture, Rawalpindi, Pakistan.

78. Jabbar, J., Malik, S. I., AlFarsi, G., \& Tawafak, R. M. (2021). The impact of WhatsApp on employees in higher education. In recent advances in intelligent systems and smart applications (pp. 639-651). Springer, Cham.

79. Jackson, L. A., Eye, A. V., Witt, E. A., Zhao, Y., \& Fitzgerald, H. E. (2011). A longitudinal study of the effects of Internet use and videogame playing on academic performance and the roles of gender, race and income in these relationships. Computers in Human Behavior, 27, 228-239. https://doi.org/10.1016/j.chb.2010.08.001 
80. Janaki, M., \& Sunanda, H. (2018). Impact of information and communication technology (ICT) on health care. Asian Journal of Development Matters, 12(1), 138-142.

81. Johanson, G. A., \& Brooks, G. P. (2010). Initial scale development: Sample size for pilot studies. Educational and Psychological Measurement, 70(3), 394-400. https://doi.org/10.1177/0013164409355692

82. Johnson, R. B., \& Christensen, L. (2019). Educational research: Quantitative, qualitative, and mixed approaches, (7th ed.). Sage.

83. Judge, S. (2005). The impact of computer technology on academic achievement of young African American children. Journal of Research in Childhood Education, 20(2), 91-101. https://doi.org/10.108 $0 / 02568540509594554$

84. Kazi, A. M., \& Khalid, W. (2012). Questionnaire designing and validation. Journal of the Pakistan Medical Association, 62(5), 514-516.

85. Kim, D., So, H. J., \& Ryoo, D. (2021). Unpacking teachers' concerns about CT-based pedagogy: The case of software education in Korea. Computer Applications in Engineering Education, 29(1), 66-82. https://doi.org/10. $1002 /$ cae. 22343

86. Kundu, A. (2021). A sound framework for ICT integration in Indian teacher education. International Journal of Teacher Education and Professional Development, 4(1), 49-67. https://doi.org/10.4018/IJTEPD.2021010104

87. Lamb, K., Humphreys, C., \& Hegarty, K. (2021). Research ethics in practice: challenges of using digital technology to embed the voices of children and young people within programs for fathers who use domestic violence. Research Ethics, 17(2), 176-192. https://doi.org/10.1177/1747016120936324

88. Larsson, J., Williams, P., \& Zetterqvist, A. (2021). The challenge of conducting ethical research in preschool. Early Child Development and Care, 191(4), 511-519. https://doi.org/10.1080/0300 4430.2019.1625897

89. Lavrakas, P. J. (2008). Self-administered questionnaire. Encyclopedia of survey research methods, Sage.

90. Lee, K. C., \& Wessol, J. L. (2021). Pilot Studies: Considerations in nursing education. Nurse Educator, 46(1), 12-13. https://doi.org/10.1097/NNE.0000000000000868

91. Letchumanan, M., Husain, S. K. S., Ayub, A. F. M., Chau, K. T., Radzi, F. I. M., \& Heng, I. C. (2020). Investigating factors that promote higher order thinking skills in Information and Communication Technology (ICT) integrated classes. Universal Journal of Educational Research, 8(11), 5816-5823. https://doi.org/10.131 89/ujer.2020.082215

92. Leung, A. A., Denham, C. R., Gandhi, T. K., Bane, A., Churchill, W. W., Bates, D. W., \& Poon, E. G. (2015). A safe practice standard for barcode technology. Journal of Patient Safety, 11(2), 89-99.

93. Leung, L., \& Lee, P. S. N. (2012). Impact of internet literacy, internet addiction symptoms, and internet activities on academic performance. Social Science Computer Review, 30(4), 403-418.

94. Li, L., \& Wang, X. (2021). Technostress inhibitors and creators and their impacts on university teachers' work performance in higher education. Cognition, Technology \& Work, 23(2), 315-330.

95. Lorah, J. A., \& Valdivia, M. (2021). Diversity in statistics education at postsecondary institutions. International Journal of Research in Undergraduate Mathematics Education, 7(1), 21-32.

96. Lu, D., Ruan, B., Lee, M., Yilmaz, Y., \& Chan, T. M. (2021). Good practices in harnessing social media for scholarly discourse, knowledge translation, and education. Perspectives on Medical Education, 10(1), 23-32.

97. Manojlovich, M., Adler-Milstein, J., Harrod, M., Sales, A., Hofer, T. P., Saint, S., \& Krein, S. L. (2015). The effect of health information technology on health care provider communication: A mixed-method protocol. JMIR Research Protocols, 4(2), e72. https://doi.org/10.2196/resprot.4463

98. Marín, V. I., Carpenter, J. P., \& Tur, G. (2021). Pre-service teachers' perceptions of social media data privacy policies. British Journal of Educational Technology, 52(2), 519-535. https://doi.org/10.1111/bjet.13035

99. McGarr, O. (2021). The use of virtual simulations in teacher education to develop pre-service teachers' behaviour and classroom management skills: implications for reflective practice. Journal of Education for Teaching, 47(2), 274-286. https://doi.org/10.1080/02607476.2020.1733398

100.McGarr, O., \& McDonagh, A. (2021). Exploring the digital competence of pre-service teachers on entry onto an initial teacher education programme in Ireland. Irish Educational Studies, 40(1), 115-128.

101.McKenney, S., \& Reeves, T. C. (2021). Educational design research: Portraying, conducting, and enhancing productive scholarship. Medical Education, 55(1), 82-92. https://doi.org/10.1111/medu.14280

102.Mertler, C. A. (2021). Introduction to educational research. Sage publications.

103.Mishra, P., Pandey, C. M., Singh, U., Gupta, A., Sahu, C., \& Keshri, A. (2019). Descriptive statistics and normality tests for statistical data. Annals of Cardiac Anaesthesia, 22(1), 67-72.

104.Moersch, C. (2010). Loti turns up the heat. Learning \& Leading with Technology, 37(5), 20-23.

105.Muslimat, A., Muhsin, H., Wahid, H. A., Yulistiana, I., Sunarsi, D., Dewi, K., ... \& Ilham, D. (2021). Develop technology based multimedia for Indonesian teachers. Journal of Contemporary Issues in Business and Government, 27(1), 1871-1882.

106. National Commission on Excellence in Education. (1983). A nation at risk: The imperative for educational reform. US Department of Education.

107.Nemcek, F. (2013). A progressive approach to integrating education technology. Techniques Connecting Education and Careers, 88(1), 32-35. 
108.Nguyen, N. (2021). Rethinking activist educational research: definitions, methodologies, and ethics. Critical Studies in Education, 62(2), 258-273. https://doi.org/10.1080/17508487.2019.1630458

109.Nikolopoulou, K. (2018). Creativity and ICT: Theoretical approaches and perspectives in school education. In Research on e-Learning and ICT in Education (pp. 87-100). Springer, Cham.

110.Nikolopoulou, K., Gialamas, V., Lavidas, K., \& Komis, V. (2021). Teachers' readiness to adopt mobile learning in classrooms: A study in Greece. Technology, Knowledge and Learning, 26(1), 53-77.

111. Ningrum, H. U., Mulyono, M., \& Isnarto, I. (2020). Mathematical connection ability based on self-efficacy in IDEAL problem solving model assisted by ICT. Unnes Journal of Mathematics Education Research, 9(2), 139146.

112.Pakistan Education Statistics. (2018). National education management information system academy of educational planning and management, Ministry of Federal Education and Professional Training, Government of Pakistan, Islamabad.

113.Papadakis, S. (2016). Creativity and innovation in European education. Ten years eTwinning. Past, present and the future. International Journal of Technology Enhanced Learning, 8(3), 279-296.

114.Pinho, C., Franco, M., \& Mendes, L. (2021). Application of innovation diffusion theory to the E-learning process: higher education context. Education and Information Technologies, 26(1), 421-440. https://doi.org /10.1007/s10639-020-10269-2

115.Prendes-Espinosa, P., Solano-Fernández, I. M., \& García-Tudela, P. A. (2021). EmDigital to Promote Digital Entrepreneurship: The Relation with Open Innovation. Journal of Open Innovation: Technology, Market, and Complexity, 7(1), 63-77. https://doi.org/10.3390/joitmc7010063

116.Qaddumi, H., Bartram, B., \& Qashmar, A. L. (2021). Evaluating the impact of ICT on teaching and learning: A study of Palestinian students' and teachers' perceptions. Education and Information Technologies, 26(2), 18651876. https://doi.org/10.1007/s10639-020-10339-5

117.Rehman, S., Gujjar, A. H., Khan, S. A. \& Iqbal, J. (2009). Quality of teaching faculty in public sector universities of Pakistan as viewed by teachers themselves. International Online Journal of Educational Sciences, 1(1), 48-63.

118. Rodríguez-Abitia, G., \& Bribiesca-Correa, G. (2021). Assessing digital transformation in universities. Future Internet, 13(2), 52-68. https://doi.org/10.3390/fi13020052

119.Rose, L. C., Gallup, A. M., Dugger, J, W. E., \& Starkweather, K. N. (2004). The second installment of the ITEA/Gallup poll and what it reveals as to how Americans think about technology. The Technology Teacher, 64(1), 1-12.

120.Rosenberg, H., \& Asterhan, C. S. (2018). WhatsApp, teacher-student perspectives on teacher-student WhatsApp interactions in secondary schools. Journal of Information Technology Education: Research, 17(1), 205-226. https://doi.org/10.28945/4081

121. Rossouw, A., Hacker, M., \& de Vries, M. J. (2011). Concepts and contexts in engineering and technology education: An international and interdisciplinary Delphi study. International Journal of Technology and Design Education, 21(4), 409-424. https://doi.org/10.1007/s10798-010-9129-1

122. Roussou, M. (2004). Learning by doing and learning through play: An exploration of interactivity in virtual environments for children. Computers in Entertainment, 2(1), 1-23. https://doi.org/10.1145/973801.973818

123.Sack-Min, J. (2007). Building the perfect school: As school design moves into the 21st century, architects and planners look at trends that are taking hold. American School Board Journal, 194(10), 16-31.

124.Saldaña, J. (2021). The coding manual for qualitative researchers. Sage.

125.Sharma, D. M. (2021). Influence of ICT and its dynamic change in daily life of human being. Journal of Contemporary Issues in Business and Government, 27(3), 635-639.

126.Shkvyr, O., Haidamashko, I., \& Tafintseva, S. (2020). Developing critical thinking in younger pupils using ICT. BRAIN. Broad Research in Artificial Intelligence and Neuroscience, 11(2), 230-242.

127.Silber-Varod, V., Eshet-Alkalai, Y., \& Geri, N. (2019). Tracing research trends of 21st-century learning skills. British Journal of Educational Technology, 50(6), 3099-3118. https://doi.org/10.1111/bjet.12753

128.Singh, A. S., \& Masuku, M. B. (2014). Normality and data transformation for applied statistical analysis. International Journal of Economics, Commerce and Management, 2(7), 1-11.

129.Sittig, D. F., Singh, H. (2010). A new socio-technical model for studying health information technology in complex adaptive healthcare systems. Quality and Safety in Health Care, 19(3), 68-74.

130.Sofwan, M., Pratama, R., Muhaimin, M., Yusnaidar, Y., Mukminin, A., \& Habibi, A. (2021). Contribution of technology innovation acceptance and organizational innovation climate on innovative teaching behavior with ICT in Indonesian education. Qwerty-Open and Interdisciplinary Journal of Technology, Culture and Education, 16(1), 33-57. https://doi.org/10.30557/QW000035

131.Song, Y., \& Zhao, X. (2021). Normality testing of high-dimensional data based on principle component and Jarque-Bera statistics. Stats, 4(1), 216-227. https://doi.org/10.3390/stats4010016

132.Stockemer, D. (2019). Quantitative methods for the social sciences a practical introduction with examples in SPSS and Stata, Springer. https://doi.org/10.1007/978-3-319-99118-4 
133.Sulisworo, D., Ummah, R., Nursholikh, M., \& Raharjo, W. (2020). The analysis of the critical thingking skills between blended learning implementation; Google classroom and schoology. Universal Journal of Educational Research, 8(3), 33-40. https://doi.org/10.13189/ujer.2020.081504

134.Supardi, S., Juhji, J., Azkiyah, I., Muqdamien, B., Ansori, A., Kurniawan, I., \& Sari, A. F. (2021). The ICT basic skills: contribution to student social media utilization activities. International Journal of Evaluation and Research in Education, 10(1), 222-229. https://doi.org/10.11591/ijere.v10i1.20598

135.Sutherland, R. V., Armstrong, S., Barnes, R., Brawn, N., Breeze, M., Gall, S., Matthewman, F., Olivero, A., Taylor, P., Triggs, J., Wishart, \& John. P. (2004). Transforming teaching and learning: Embedding ICT into everyday classroom practices. Journal of Computer Assisted Learning, 20(6), 413-425.

136.Terrell, S. R. (2021). Statistics translated: A step-by-step guide to analyzing and interpreting data. Guilford Publications.

137.Tlili, A., Zhang, J., Papamitsiou, Z., Manske, S., Huang, R., \& Hoppe, H. U. (2021). Towards utilizing emerging technologies to address the challenges of using open educational resources: a vision of the future. Educational Technology Research and Development, 69(2), 515-532.

138. Thomas, G. (2021). How to do your case study. Sage.

139.Usman, S. (2014). Governance and higher education in Pakistan: What roles do boards of governors play in ensuring the academic quality maintenance in public universities versus private universities in Pakistan. International Journal of Higher Education, 3(2), 38-51. https://doi.org/10.5430/ijhe.v3n2p38

140.Utts, J. M., \& Heckard, R. F. (2021). Mind on statistics. Cengage Learning.

141.Van Belle, G. (2011). Statistical rules of thumb (Vol. 699). John Wiley \& Sons.

142.Van Truong, D., \& Huyen, T. V. (2021). How to use SPSS software to help students in scientific research. International Journal of Educational Research, 4(05), 83-89.

143.Wenglinsky, H. (2005). Technology and achievement the bottom line. Educational Leadership, 63(4), $29-32$.

144.Wentworth, D. K., \& Middleton, J. H. (2014). Technology use and academic performance. Computers \& Education, 78, 306-311. https://doi.org/10.1016/j.compedu.2014.06.012

145.Winn, W., \& Jackson, R. (1999). Fourteen propositions about educational uses of virtual reality. Educational Technology, 39(4), 5-14.

146. Wongwuttiwat, J., \& Winley, G. K. (2020). An exploration of creativity traits among ICT lecturers and students in Thailand. Journal of Education for Business, 95(6), 408-418. https://doi.org/10.1080/08832323.20 19.1664374

147. Yamane, T. (1967). Statistics, an introductory analysis, (2nd ed.). Harper and Row.

148. Yen, P. Y., McAlearney, A. S., Sieck, C. J., Hefner, J. L., \& Huerta, T. R. (2017). Health information technology (HIT) adaptation: Refocusing on the journey to successful HIT implementation. JMIR Medical Informatics, 5(3), e28. https://doi.org/10.2196/medinform.7476

149.Zawacki-Richter, O., Latchem, C. (2018). Exploring four decades of research in computers \& education. Computers and Education, 122(1), 136-152. https://doi.org/10.1016/j.compedu.2018.04.001

150.Zina, O. (2021). The essential guide to doing your research project. Sage.

151.Zuga, K. F. (2004). Improving technology education research on cognition. International Journal of Technology and Design Education, 14(1), 79-87. https://doi.org/10.1023/B:ITDE.0000007360.33705.94

152.Zyphur, M. J., \& Pierides, D. C. (2020). Making quantitative research work: From positivist dogma to actual social scientific inquiry. Journal of Business Ethics, 167(1), 49-62. https://doi.org/10.1007/s10551-019-04189-6 